DOI: https://doi.org/10.15407/techned2021.06.068

\title{
INCREASING THE SENSITIVITY AND METROLOGICAL RELIABILITY OF A DIFFERENTIAL CONDUCTOMETRIC BIOSENSOR SYSTEM
}

\author{
V.G. Melnyk ${ }^{1^{*}}$, P.I. Borshchov ${ }^{1^{* *}}$, S.V. Dzyadevych ${ }^{2 * * *}$, O.Y. Saiapina ${ }^{2^{* * * *}}$, O.D. Vasylenko $^{1^{* * * * * *}}$ \\ ${ }^{1}$ Institute of Electrodynamics National Academy of Sciences of Ukraine, \\ Peremohy ave., 56, Kyiv, 03057, Ukraine. \\ E-mail: $\quad$ melnik@ied.org.ua \\ ${ }^{2}$ Institute of Molecular Biology and Genetics National Academy of Sciences of Ukraine, \\ Zabolotnoho st., 150, Kyiv, 03680, Ukraine. \\ E-mail: $\quad$ dzyad@yahoo.com; oysaiapina@gmail.com
}

The differential method of conductometric measurements does not fully solve the problem of the influence of changes in the background electrical conductivity of the working buffer solutions on the results of conversion of the biosensor responses. The variation in the background electrical conductivity of the buffer solution upon addition of the highly conductive analyte acts as a common mode interference and causes the additive error. Here we present a new measurement method and structure of the device for quantification of the analytes that provide a significant decrease in the measurement error associated with a change in the background electrical conductivity caused by the introduction of the analyte to the working solution prior to the generation of the informative signal. A block diagram of the device and a vector model of the balancing process of its measuring circuit are presented. The advantages of the developed method and biosensor analyzer for application within the possible changes of the transducer parameters and measurement conditions are demonstrated. References 37, figures 4.

Keywords: differential conductometric biosensors, impedance, measurement, common mode interferences, equivalent electrical model.

1. Introduction. One of the main trends in biosensorics [1-3] is the improvement of electrochemical biosensors, in particular, those of the conductometric type. Their advantages are high sensitivity and selectivity, ease of use, high speed of analysis, and a wide range of analytes that can be detected (hereafter the generalized term "analyte" will denote the substance of interest, for which the analysis is performed). Additionally, a significant advantage is the low cost of analysis in general since there is no need in the preliminary sample preparation [4-8]. At the same time, the implementation of electronic measuring channels of conductometric biosensor systems [9-11] requires overcoming difficulties associated with the complex dependence of the informative signal of the measuring circuit on the parameters of the equivalent circuit of conductometric converters $[12,13]$ and the measurement environment. This apparently explains the lack of available publications by other authors on successful developments in this area.

The causes and methods for overcoming the individual parts of this problem we studied in our earlier works [14-15]. First, in [16-19], the effectiveness of a conductometric differential method in biosensors has been shown. The method is based on measurement of the local changes in the solution conductivity caused by the analyte-probe interaction in a selective (active) membrane of a biosensor, immobilized on the interdigitated electrodes of a working transducer (W), relative to the reference transducer (R) with a nonselective (hereinafter referred to as "passive") membrane (Fig. 1). In principle, the use of this method makes it possible to select small informative changes in the electrical conductivity of the solution in a bioselective membrane at high values of the background electrical conductivity of the buffer solution and, thus, to increase significantly the sensitivity and selectivity of the biosensor system. However, often the background conductivity is several orders of magnitude greater than the dynamic range of the measured value. The changes in background conductivity act as common mode interference during measurements.

\footnotetext{
(C) Melnyk V.G., Borshchov P.I., Dzyadevych S.V., Saiapina O.Y., Vasylenko O.D., 2021

ORCID ID: * https://orcid.org/0000-0002-4470-4339; ${ }^{* *}$ https://orcid.org/0000-0003-1363-9252;

${ }_{* * * * *}^{* *}$ https://orcid.org/0000-0003-2915-716X; ${ }^{* * * *}$ https://orcid.org/0000-0003-2937-9221;

***** https://orcid.org/0000-0002-1043-9426
} 
Therefore, it is relevant to construct a measuring channel with a large common mode rejection ratio (CMRR).

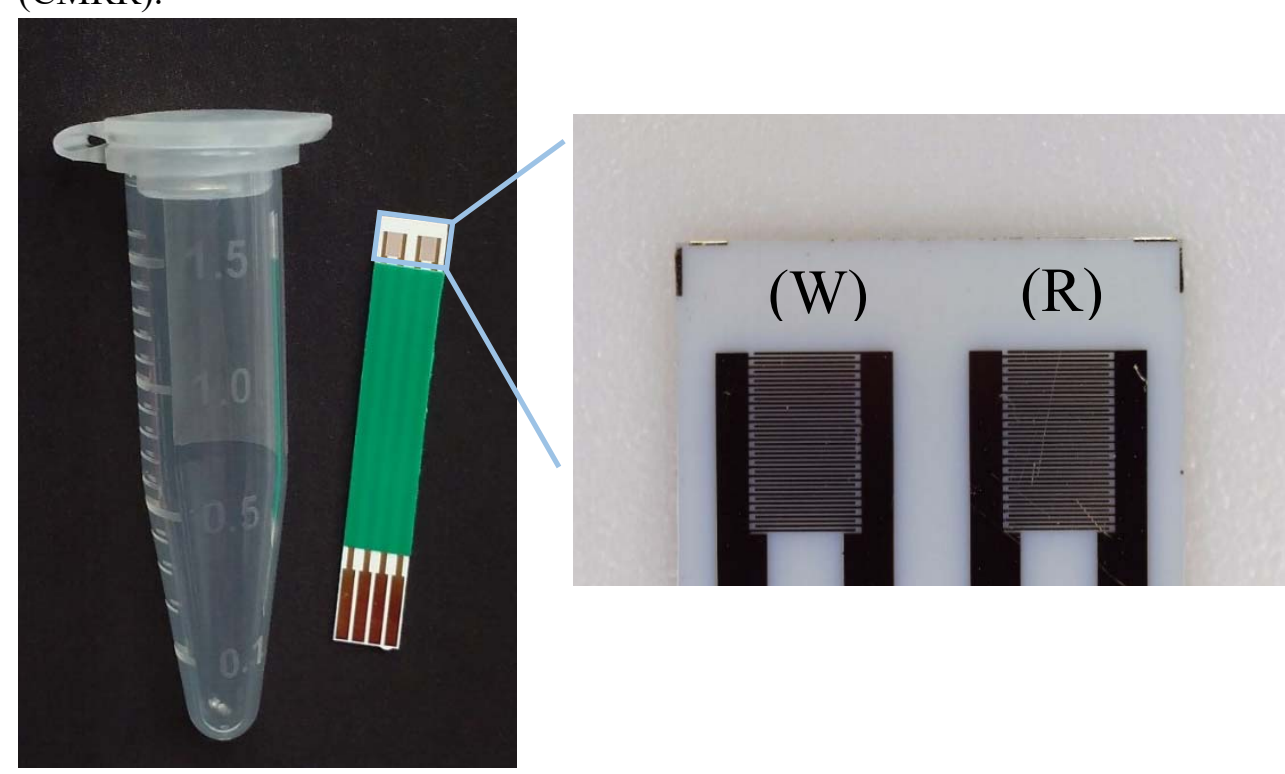

Fig. 1
Additionally, the output signals of conductometric converters depend on changes in the buffer solution composition and temperature that are considered as the noninformative changes. In the differential measuring system, these noninformative physical quantities are converted both by the active and nonselective membranes. If characteristics of the working and reference converters are identical, then upon mutual subtraction of

their output signals in the measuring circuit, the background components compensate each other and only informative signal remains. The later corresponds to a local change in electrical conductivity in the working converter due to the biochemical reaction.

In existing biosensors, the conductometric converters are designed as the planar electrode pairs of an interdigitated comb topology. Platinum, gold, stainless steel and nickel can be used as the electrode materials. Converters with platinum electrodes have the best electrical characteristics, but they are expensive and have insufficient service life. Gold electrodes are used most often because of their chemical inertness and excellent properties with respect to immobilization of the bio-materials. Unfortunately, the equivalence of parameters of such transducers in the biosensor's differential pair is much lower than required. This is due to the following reasons: (1) wear of gold; (2) the change in the capacitance of the electrochemical double layer formed at the metal/electrolyte interface during reuse of transducers. The current work was devoted to the study and reducing of the impact of the second factor as more significant.

A common problem of using two-electrode converters in conductometry is the presence of nearelectrode impedances in them. The relationship between the parameters of these impedances and electrochemical processes in the measurement cell as well as to the practical use of the results obtained have been widely studied in the literature [20-24]. These impedances are added to the resistance of the solution between electrodes. In the simplest case (at a frequency of test signals of several tens of $\mathrm{kHz}$ ), the total impedance of the transducer can be represented by a near-electrode capacitance $\mathrm{C}_{\mathrm{S}}$ with the connected in parallel polarization resistance $R_{P}$, which in turn are connected in series with the solution's resistance $R_{S}$. The behavior of such impedance is quite accurately described by an equivalent circuit in the form of a series chain $\left(C_{S}\right.$ and $\left.R_{S}\right)$, if the reactance at the frequency of the test signal $\left(1 / \omega C_{S}\right)$ is significantly less than $R_{S}$ and $R_{P}$. Such ratios are typical for platinum electrodes whereas for gold electrodes $1 / \omega C_{S}$ and $R_{S}$ are comparable (the tangent of the phase angle $\tan \varphi=1 / \omega C_{S} R_{S}$ reaches 0.5 and even 1.0). If $R_{P}>1 / \omega C_{S}$, the equivalent circuit can be adopted in series, but $\mathrm{R}_{\mathrm{S}}$ will be slightly changed.

The measuring channels with differential conductometric biosensors are based on the bridge circuits. At large values of $\tan \varphi$, their sensitivity sharply decreases. This disadvantage is significantly eliminated in the bridge circuits with the compensation of the voltage drop on $C_{S}$ [14]. If $C_{S}$ and $R_{S}$ of the working and reference converters are identical, CMRR of such circuits are high.

Unfortunately, when using sensors with gold electrodes it is difficult to obtain a stable conversion factor between specific solution conductivity and the informative component of the bridge output signal. Such a component is an increase in the in-phase (with respect to the test signal) component of the output current of the bridge circuit triggered by the analyte-probe interaction in the active membrane of the biosensor. This informative component depends on the ratio of $C_{S}$ and $R_{S}$ in the working and reference 
converter (their $\tan \varphi$ ). If they are the same, then the same changes in the active component of their electrical conductivity $\left(1 / \mathrm{R}_{\mathrm{S}}\right)$ do not disrupt the bridge balance. Therefore, its output signal does not change upon the changes in the background conductivity of the buffer solution. For a fixed concentration of the buffer solution, the value of $R_{S}$ is determined by the dimensions and mutual arrangement of the electrode combs. The interdigitated comb electrodes are manufactured using microelectronic technologies, so the accuracy of the $\mathrm{R}_{\mathrm{S}}$ parameter is quite high.

However, the transducer impedance has complex nature with a large phase angle, which depends on the value of $\mathrm{C}_{\mathrm{S}}$. This parameter is unstable [15]. Therefore, the same changes in the background electrical conductivity in the working and reference converters will cause different changes of the currents across them. The difference in these currents forms a response to such (common mode) interference at the bridge output. The background conductivity of the buffer solution changes when the analyte is added, especially if the latter is electrically conductive.

The effect of common mode interference in the differential conductometric channel does not distinguish from the response to a change in the local electrical conductivity in the active (selective) membrane of the biosensor. Thus, it is an additive error, which significantly limits the real sensitivity of the conductometric system and the reliability of the measurement results [14].

There are many practically important tasks where measurement of concentration of electrically conductive (dissociated) analytes is of high topicality. A typical example is the problem of determining the arginine content in multicomponent mixtures. Determination of the amino acid arginine (2-amino-5guanidinovaleric acid) is of great practical importance for the quality control of juices and functional foods. In the food industry, the monitoring of arginine concentration makes it possible to control the quality of the packed fruit juices for the presence of falsification. This is because the adulterated fruit juices differ from the authentic ones in the amino acid profile in terms of arginine [25], which occurs when a more expensive (authentic) juice is diluted with a cheaper one. Among the proteinogenic amino acids, arginine is the most polar positively charged amino acid at a neutral $\mathrm{pH}$ value $(\mathrm{pI} 10.76)$ due to the presence of a guanidinium group [26] and this may cause challenges during its quantitative analysis. The reported in the literature electrochemical biosensors for arginine are based on one or several enzymes, which decompose arginine to electroactive and/or highly mobile species [27-31]. According to the analytical characteristics of the most recent biosensors for arginine, the conductometric biosensor described in [27] had one of the lowest limit of detection, the widest linear range and the highest stability compared to other reported biosensors. However, the mentioned biosensor did not show sufficient selectivity to arginine when working with multicomponent samples. We attribute this disadvantage to the possible effect of common mode interference, which manifests itself through high background electrical conductivity of the arginine solutions used throughout analysis.

The aim of this work was to increase the degree of suppression of common mode interference in a differential conductometric biosensor system with incomplete equivalence of parameters of transducers in the biosensor's differential pair and, thereby to increase sensitivity of the system and reliability of the measurement results.

2. Bridge circuit and measurement method. A research, which we have done over the past few years, has allowed us to create a technical basis for a radical increase in CMRR of differential conductometric channels with non-identical sensors [32-35]. A comprehensive analysis of measurement processes in the previously developed differential conductometric circuits [14] allowed us to develop a measurement method with quasi-equilibrium of the bridge circuit, which theoretically allows eliminating in great degree the above error [32]. Its essence lies in bringing the bridge circuit with non-identical conductometric transducers to a state with a calculated deviation from complete equilibrium before adding the analyte to the buffer solution in the measurement cell. The calculated deviation should ensure that the increase in currents across the working and reference converters was equal in magnitude and opposite in phase at the equal changes in the buffer solution conductivity in them. However, the implementation of this method within the frameworks of the construction principles applied to the previously used bridge circuits turned out to be too complex. In [33], we proposed to use the bridge circuits with two digital generators of test signals, the phase shift between which can be accurately controlled. The latest results obtained in the implementation of such generators [34] made it possible to develop the quasi-balanced bridge circuits and algorithms for their operation in practice. The corresponding developments are presented and discussed below. 


\section{Results and discussion.}

3.1 The structure of a biosensor channel with a wide range of operating frequencies based on a bridge circuit with a two-phase generator of test signals. The proposed structure of a conductometric channel with a bridge measuring circuit, which is balanced by the modulus and phase of the currents in its branches, is shown in Fig. 2. It is adapted to solve the problems of the differential conductometry with increased levels of common mode interference caused by the background changes in the conductivity of solution. Such device was implemented using the unified basic measuring module MXP-6 [34] for measurement of the impedance parameters.

The measurement circuit of the basic module MXP-6 includes a measurement object, a reference standard and two coherent digital generators of test signals - a master DG1 and a slave DG2. Blocks $\mathrm{DAC}_{\mathrm{B}}$ and PHASE SHIFT regulate the voltage of DG2 in modulus and phase.

The basic feature of this scheme is that the standard (etalon) of electrical conductivity $\mathbf{Y 0}$ is replaced by the reference conductometric transducer $Z_{p}$. In the ideal case, the



Fig. 2 parameters of the working $\mathbf{Z}_{\mathrm{a}}$ and reference $\mathbf{Z}_{\mathrm{p}}$ transducers (and, accordingly, their complex conductivity $\mathbf{Y}_{\mathrm{a}}$ and $\mathbf{Y}_{\mathrm{p}}$ ) are the same before measurements. The bridge circuit is balanced. When the analyte is added to the buffer solution, the additional active con-ductivity appears in the working transducer $\left(\mathbf{Y}_{\mathrm{a}}+\boldsymbol{\Delta} \mathbf{G}_{\mathrm{a}}\right)$, which leads to a change in the output signal of the bridge proportionally to the measured value - the conductivity difference $\left(\mathbf{Y}_{\mathrm{a}}+\Delta \mathbf{G}_{\mathrm{a}}-\mathbf{Y}_{\mathrm{p}}\right)$. This difference is determined by the change in the amplitude of the output current of the bridge circuit $\left(\boldsymbol{I}_{\mathrm{a}}-\boldsymbol{I}_{\mathrm{p}}\right)$. The normalization of its value in the units of electrical conductivity is carried out not in the bridge circuit (by comparing $\mathbf{Y}_{\mathrm{a}}$ and $\mathbf{Y}_{\mathrm{p}}$ ) but in ADC by comparing the in-phase and quadrature components of the $\boldsymbol{U}_{\mathrm{X}}$ signal (relative to $\boldsymbol{U}_{\mathrm{a}}$ ) with the reference voltage $\boldsymbol{U}_{\text {ref }}$. Taking into account the features of the structure of the measuring circuit, the object of measurements and the measured parameter, the additional mode of differential conductometric measurements was introduced into the software algorithm of the basic module of the device.

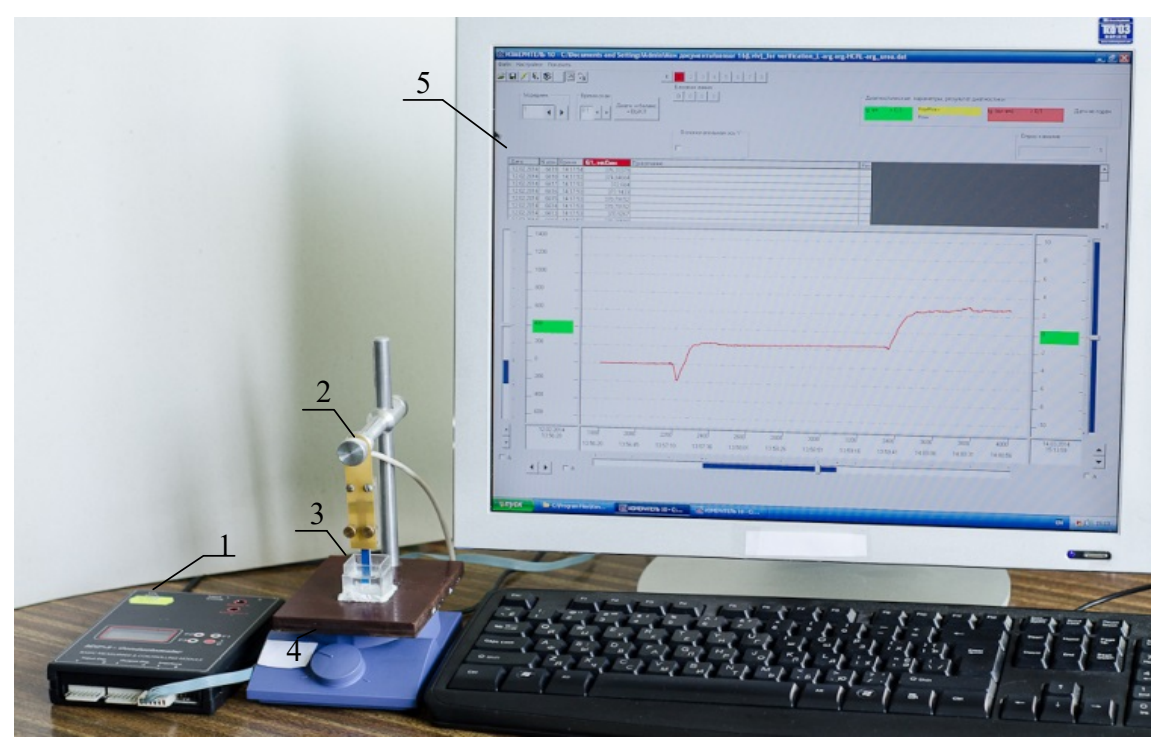

Fig. 3 Next, we will focus on procedure of measurements with biosensors.

3.2 Measurement of the analyte concentration using the developed conductometric biosensor system. A process of measurement of the concen-tration of the analyte in the measurement cell consists of two stages. First, the measuring channel, which includes the measu-rement cell with a differential biosensor (a pair of conduc-tometric transducers with the active and passive membranes) and an electronic measuring module with the necessary software (Fig. 3), is 
adjusted by software. This module is connected to a personal computer with the corres-ponding upper-level software package through a standard interface. The measurement data obtained from the electronic module (the lower level of the information measuring system) are processed, accumulated and presented to the user by the software created in the work.

At the first stage, the mentioned above hardware and software adjustments are performed to bring the measuring channel into a state of readiness for the introduction of the analyte into the measurement cell. This state is achieved by balancing the bridge circuit of the measuring module and is characterized by a conditionally zero signal level at the output. At the upper level of the information measuring system, a "baseline" is recorded; it corresponds to the real-time data flow in the active membrane of the biosensor before the introduction of the analyte.

At the second stage of measurements, a certain amount of analyte is added to the measurement cell. In general, this changes the values of $\mathrm{R}_{\mathrm{Sa}}$ and $\mathrm{R}_{\mathrm{Sp}}$ of the converters of differential pair (if they are identical, the changes are the same). Next, a selective biochemical reaction takes place in the active membrane of the biosensor that consequently changes the solution conductivity locally by $\Delta \mathrm{G}_{\mathrm{a}}$. At the same time, the active component of the output impedance of the working converter changes by a value inversely proportional to $\Delta \mathrm{G}_{\mathrm{a}}$. With the correct construction of the measuring circuit and setting the measuring channel to the state of readiness, the response to the introduction of the analyte is generated at the channel output proportionally to the analyte concentration in the solution. Noteworthy that the response is proportional to the analyte concentration only when the working and reference converters are identical or at least their phase angles are equal and their tangents are small. Under other conditions, the variation of the background electrical conductivity of the buffer solution (due to appearance of a new substance, i.e. the analyte molecules) causes a parasitic response at the output of the bridge circuit [36]. This response is an additive error of the measurements. As mentioned above, it is possible to tune the bridge circuit so that the parasitic response will not occur [32].

3.3 Vector model and algorithm of adjusting the bridge circuit to achieve the invariance of the response of the measuring channel to changes in the background electrical conductivity under the discrepancy of the phase angles of the conductometric transducers. Let us consider the process of tuning a bridge circuit by balancing the phases and amplitudes of currents in the branches of the working and reference converters according to the optimized algorithm. The latter ensures that the equal changes of electrical conductivity in the working and reference transducers with different values of $R_{S}$ and $C_{S}$ are mutually compensated in the output signal of the bridge. The vector diagram of this process described by the

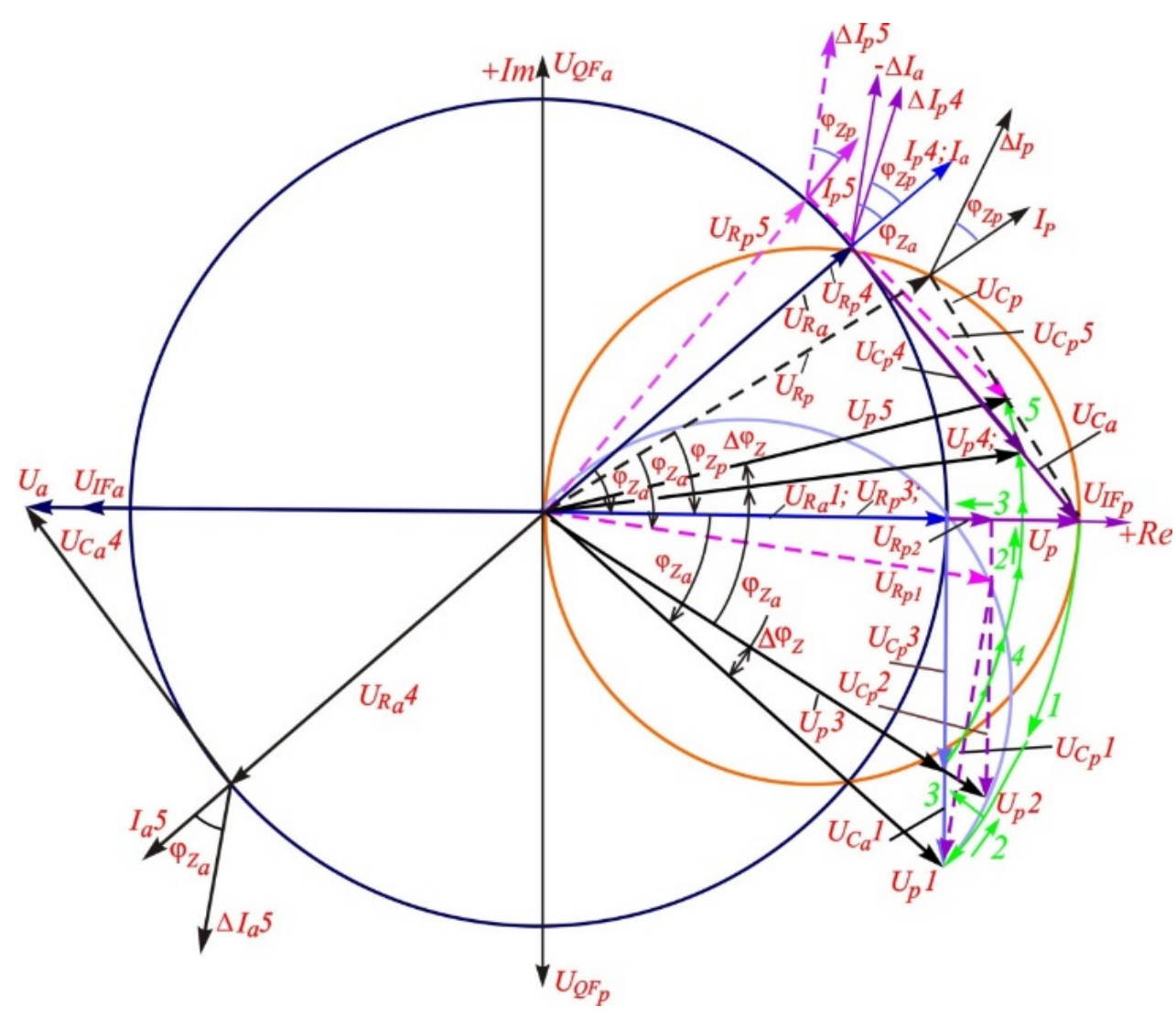
scheme in Fig. 2 is shown in Fig. 4. To simplify it, an assumption was made that the active resistances of the transducers differ insignificantly (ensured by the accuracy of the electrode fabrication technologies) and the difference in their phase angles originates from changes in the condition of the electrode surface, which leads to the changes in $\mathrm{C}_{\mathrm{S}}$.

The axes of the complex plane Im and Re are determined by the reference voltages of the synchronous detector $\boldsymbol{U}_{\mathbf{I F a}}, \boldsymbol{U}_{\mathrm{QFa}}$, which are formed by the digital 
generator DG1. The vectors in the diagram (Fig. 4) represent the moduli and phases of voltages at the impedances $\mathbf{Z}$ of the active (a) and passive (p) transducers of the differential biosensor (the terms "active" and "passive" correspond to the working and reference transducers, respectively). These impedances are the parameters of a series two-element equivalent $\mathrm{RC}$ circuit, in which $\mathrm{R}_{\mathrm{S}}$ corresponds to the resistance of solution, and $\mathrm{C}_{\mathrm{S}}$ corresponds to the resistance of the near-electrode layer, in which the capacitive component prevails at the operating frequency of the device. The minority components of the complex resistances of both the solution and the near-electrode layer (the interelectrode capacitance $C_{i e}$ and the resistance of polarization $R_{p o l}$ are parallel to $R_{S}$ and $C_{S}$, respectively [33]) are recalculated into a small change of $R_{S}$ and $\mathrm{C}_{\mathrm{S}}$ when the measurements are carried out using a two-element scheme. To reduce these changes, the operating frequency should be optimized accordingly.

In the two-element equivalent circuit of the conductometric transducer, the applied test voltage from the generator output $\left(\boldsymbol{U}_{\mathbf{a}}\right.$ or $\left.\boldsymbol{U}_{\mathbf{p}}\right)$ is divided into two components: $\boldsymbol{U}_{\mathbf{R a}}$ or $\boldsymbol{U}_{\mathbf{R p}}$ on the solution resistance and $\boldsymbol{U}_{\mathrm{Ca}}$ or $\boldsymbol{U}_{\mathrm{Cp}}$ on the capacitance of the near-electrode layer. These components are orthogonal to each other.

The currents across the converters coincide in phase with the voltage $\boldsymbol{U}_{\mathbf{R a}}$ or $\boldsymbol{U}_{\mathbf{R p}}$, and their moduli are inversely proportional to $\mathrm{R}_{\mathrm{Sa}}$ or $\mathrm{R}_{\mathrm{Sp}}$, respectively. If $\mathrm{R}_{\mathrm{Sa}}$ equals $\mathrm{R}_{\mathrm{Sp}}$, and $\mathrm{C}_{\mathrm{Sa}}$ equals $\mathrm{C}_{\mathrm{Sp}}$, these currents will be the same in magnitude and phase. In this case, the voltage triangles $\boldsymbol{U}_{\mathrm{a}}, \boldsymbol{U}_{\mathrm{Ra}}, \boldsymbol{U}_{\mathrm{Ca}}$ and $\boldsymbol{U}_{\mathrm{p}}, \boldsymbol{U}_{\mathrm{Rp}}, \boldsymbol{U}_{\mathrm{Cp}}$ will overlap if $\boldsymbol{U}_{\mathrm{a}}=\boldsymbol{U}_{\mathrm{p}}$. As shown in Fig. 4, the ratios of $\mathrm{R}_{\mathrm{S}}$ and $\mathrm{C}_{\mathrm{S}}$ in the converters of the differential pair are different. In practice, the difference reaches $10-20 \%$.

The addition of the analyte to the buffer solution causes changes in $R_{S a}$ and $R_{S p}$ by the values determined by the change in the electrical conductivity of the buffer solution in both converters. Additionally, the conductivity of $R_{\mathrm{Sa}}\left(\mathrm{G}_{\mathrm{Sa}}=1 / \mathrm{R}_{\mathrm{Sa}}\right)$ changes by the informative value $\Delta \mathrm{G}_{\mathrm{a}}$, which is proportional to the yield of the bioselective reaction in the active membrane. The indicated changes in the resistances $R_{S}$ lead to the increases in the currents across converters by $\Delta \boldsymbol{I}_{\mathrm{a}}$ and $\Delta \boldsymbol{I}_{\mathrm{p}}$. The vectors of these increases are at the phase angles of the impedances $\mathbf{Z}_{\mathrm{a}}$ and $\mathbf{Z}_{\mathrm{p}}\left(\varphi_{\mathrm{a}}\right.$ and $\left.\varphi_{\mathrm{p}}\right)$ to the vectors of the currents across converters. The values of the informative increase usually equal $1-2 \%$ of $\boldsymbol{I}_{\mathrm{a}}$. The changes of current, which are caused by variation of the background electrical conductivity dependent on nature and concentration of the analyte, should be minimal. However, in practice, they can be proportionate and even exceed the informative increase.

The vectors of the currents' growth $\left(-\Delta I_{\mathrm{a}}\right.$ and $\left.\Delta \boldsymbol{I}_{\mathrm{p}}\right)$, which correspond to the changes in the background electrical conductivity at the same voltage $\left(\boldsymbol{U}_{\mathbf{p}}\right)$ applied to the converters, are shown on the right side of the diagram in Fig. 4. Such a state of the bridge circuit is a result of its preliminary adjustment before the measurements. The sign "-" at $\Delta \boldsymbol{I}_{\mathrm{a}}$ denotes its phase to be opposite to the operating mode. At the end of the adjustment, voltage $\boldsymbol{U}_{\mathrm{a}}$ is applied to the working sensor, which is opposite in phase to $\boldsymbol{U}_{\mathrm{p}}$ at its initial state (left side of the diagram). In this case, both the currents $\boldsymbol{I}_{\mathrm{a}}$ and $\boldsymbol{I}_{\mathrm{p}}$ as well as their increments $\Delta \boldsymbol{I}_{\mathrm{a}}$ and $\Delta \boldsymbol{I}_{\mathrm{p}}$ become antiphase and compensate each other. However, the exact antiphase of these currents happens only at the same phase angles of the converters.

Additionally, the developed process of the bridge circuit tuning allows obtaining an exact antiphase of the current gains in case when the phase angles of the active and passive converters differ. The process consists of five stages indicated by indices 1 to 5 . The vectors corresponding to the initial state do not have such an index.

At the beginning of the first stage (substage 1a), the voltage $\boldsymbol{U}_{\mathrm{p}}$ is applied to $\mathbf{Z}_{\mathbf{a}}$ and its phase shift to $\boldsymbol{U}_{\mathrm{a}}$ is set to $180^{\circ}$. For this, the switches SW1 and SW2 are set to "0". The real and imaginary components of the current $\boldsymbol{I}_{\mathrm{a}}$ in $\mathbf{Z}_{\mathrm{a}}$ are measured and, from their value, the parameters of the working converter $\mathrm{R}_{\mathrm{Sa}}$ and $\mathrm{C}_{\mathrm{Sa}}$ as well as the tangent of the phase angle $\tan \varphi_{\mathrm{a}}$ are calculated and diagnosed. To carry out such calculations, the measuring channel is pre-calibrated using a reference resistor. The absence of an imaginary component in the current $\boldsymbol{I}_{\mathbf{a}}$ is achieved by adjusting the "1" phase of the vector $\boldsymbol{U}_{\mathbf{p}}$ to its position $\boldsymbol{U}_{\mathbf{p} 1}$. Such adjustment as well as the measurement of a real component $\boldsymbol{I}_{\mathrm{a}}$, which is related to the values of $\boldsymbol{U}_{\mathbf{p}}, \boldsymbol{U}_{\mathrm{Ra}}$ and $\mathrm{R}_{\mathrm{a}}$, are performed using the synchronous detector. The values of the rotation angle of $\boldsymbol{U}_{\mathrm{p}}$ and the real component $\boldsymbol{I}_{\mathrm{a}}$ can also be used to calculate and diagnose the parameters of the working converter $\mathrm{R}_{\mathrm{Sa}}$ and $\tan \varphi_{\mathrm{a}}$. Then (substage 1b) the voltage $\boldsymbol{U}_{\mathbf{p} 1}$ is switched to the reference converter by setting the switch SW1 to the position "1". In this case, the real and imaginary components of its current $\boldsymbol{I}_{\mathbf{p} 1}$ are measured, the parameters of the reference converter $R_{S p}, C_{S p}$ and $\tan \varphi_{p}$ are calculated and diagnosed, and the difference in phase angles $\Delta \varphi_{z}$ of the working and reference converters is determined. The triangles of the voltage vectors on the elements of the converter equivalent circuits consist of vectors $\boldsymbol{U}_{\mathrm{Ra} 1}, \boldsymbol{U}_{\mathrm{Ca} 1}, \boldsymbol{U}_{\mathrm{Rp} 1}, \boldsymbol{U}_{\mathrm{Cp} 1}$ and $\boldsymbol{U}_{\mathrm{p} 1}$.

At the second and third stages, the phase ("2") and the amplitude ("3") of the voltage $\boldsymbol{U}_{\mathbf{p}}$ are regulated 
to reach the states $\boldsymbol{U}_{\mathbf{p} 2}$ and $\boldsymbol{U}_{\mathbf{p} 3}$, at which the voltage $\boldsymbol{U}_{\mathbf{R p} 3}$ on $\mathrm{R}_{\mathrm{p}}$ coincides in magnitude and phase with $\boldsymbol{U}_{\mathbf{R a}}$, whereas $\boldsymbol{U}_{\mathbf{C p} 3}$ and $\boldsymbol{U}_{\mathbf{C a} 1}$ somewhat differ in amplitude. The adjustment is carried out using the conversion data of the imaginary ("2") and real ("3") components of the current $\boldsymbol{I}_{\mathbf{p}}$ obtained using the synchronous detector. Achievement of these states is fixed by the minimum of the imaginary component of $\boldsymbol{I}_{\mathrm{p}}$ and by matching of the real component with the value of the real component $\boldsymbol{I}_{\mathrm{a}}$. In the considered bridge circuit (which is based on the comparison of the currents in sensors), if there is a noticeable difference between $R_{S a}$ and $R_{S p}$, the voltages on them will also differ noticeably. For such converters, it is necessary to use another, somewhat more complex, bridge circuit - with a comparison of the voltages on the sensors. Such a scheme is problematic in terms of stability of the test voltage on the sensors, but it can be appropriate for measurements at high concentrations of the buffer solution. The performed phase adjustment also determines the value of difference of phase angles $\Delta \varphi_{z}$ of the converters.

At the beginning of the fourth stage (substage 4a), the phase of the DG2 voltage $\boldsymbol{U}_{\mathrm{p}}$ is rotated to the state $\boldsymbol{U}_{\mathrm{p} 4}$ by the value equal to the regulation "1" but in the opposite direction. At this state, the voltage on the active resistance of the reference converter $\boldsymbol{U}_{\mathbf{R p} 4}$ coincides in magnitude and phase with the voltage on the active resistance of the working converter at the initial setting. Therefore, the bridge circuit will be in an equilibrium in terms of the voltages on the resistances of the buffer solution in the converters after the antiphase voltage $\boldsymbol{U}_{\mathbf{a}}$ is applied from the generator DG1 to the working converter by setting the switch SW2 to the state "1" (substage 4b). These voltages are equal in magnitude and opposite in sign. Therefore, the amplitudes of the increase in currents $\boldsymbol{I}_{\mathrm{a}}$ and $\boldsymbol{I}_{\mathrm{p} 4}$ in the working and reference converters are the same when the background electrical conductivity changes. This effect was achieved by other means in the circuit described in [32]. In particular, that was achieved using the analog nodes, which complicated the circuit and limited its frequency range.

In the achieved state of the bridge circuit, the difference in phases of the current increments $\Delta I_{\mathrm{a}}$ and $\Delta I_{\mathrm{p} 4}$ remains. Therefore, the suppression of the influence of changes in the background electrical conductivity is insufficient at large values of $\varphi_{a}, \varphi_{p}$ and their difference. To bring the bridge circuit to a state of quasi-equilibrium, in which the vectors $\Delta \boldsymbol{I}_{\mathrm{a}}$ and $\Delta \boldsymbol{I}_{\mathrm{p}}$ become collinear, it is necessary to turn the voltage $\boldsymbol{U}_{\mathrm{p}}$ additionally by the angle $\Delta \varphi_{z}$ to the state, in which the voltage on the solution in the reference converter is shown by the vector $\boldsymbol{U}_{\mathbf{p 5}}$. Such regulation is carried out at the fifth stage of tuning (after connecting the working converter to the generator DG1). As seen in Fig. 4, the vectors of currents across the working and reference converters at the final state of the bridge after balancing are not collinear. Therefore, the bridge is not completely balanced on phase. Nevertheless, by now it is completely balanced for the further increment of currents in the converters upon the equal changes in conductivity of the solution in them. At this state, the bridge circuit is ready for the second stage of the measurement process, i.e. introduction of the analyte and registration of the response driven by the analyte-probe interaction in the biosensor. The informative signal at the "baseline" level is obtained at the output of the bridge circuit. With respect to this level, its increase ("response") is recorded when the analyte is added to the measurement cell.

To achieve a higher level of independence of the results of the response conversion on the phase angles of the converters, we measured the amplitudes of the current increase by their in-phase and quadrature components relative to the reference voltages of the DG1 generator. This somewhat complicates the processing of the informative signal, but it is not a big price to pay for the significant simplification of the measuring circuit and the higher metrological characteristics achieved in the described design.

The difference of the presented conductometric system from the previously known ones is the exact balancing of the bridge circuit both by the module and by the phase of the signals in its branches. Naturally, there is a question about the possibility of implementing a measuring channel with sufficiently low phase errors at the operating frequencies used in such systems $(30-100 \mathrm{kHz})$. This problem is solved due to the special structure of the complex of generating test and reference signals in the basic module of the measuring channel MXP-6, which provides a high identity of phase delays in their formation. The principles of construction of such a measuring channel, the results of experimental studies of its characteristics are presented in detail in $[34,35]$. According to the results of these studies, the phase error of the conversion of the measuring signal (level change of the quadrature component) in the base module does not exceed a few hundredths of a percent at frequencies up to $100 \mathrm{kHz}$. A factor that limits the accuracy of balancing the bridge circuit of the created device is the possible discreteness of the phase control of the slave generator. At the frequency used in the studies $(62.5 \mathrm{kHz})$, it was approximately $1 \%$.

3.4 Testing of the developed biosensor analyzer in the simulated measurement conditions. Experimental verification of the effectiveness of the developed method of differential measurements of the 
local changes in the electrical conductivity of solutions was carried out using a prototype of the conductometric biosensor analyzer, which was realized according to the scheme in Fig. 2, and the electrical equivalent of the measurement cell with the adjusted parameters. A description of the equivalent is given in $[36,37]$. In the studies, we simulated the maximum possible difference between the values of the uniform parameters of the working and reference converters $\mathrm{C}_{\mathrm{Sa}}$ and $\mathrm{C}_{\mathrm{Sp}}( \pm 20 \%)$ as for measurements with the real sensors. The vector diagram in Fig. 4 approximately corresponds to such difference in $\mathrm{C}_{\mathrm{Sp}}(+20 \%)$. To estimate the sensitivity of the measuring channel to informative changes in the local electrical conductivity of the solution, we simulated a $1 \%$ change in the value of electrical conductivity $\mathrm{G}_{\mathrm{Sa}}$ (resistance $\mathrm{R}_{\mathrm{Sa}}$ ) in the working sensor. At the same time, to estimate the impact of changes in the background conductivity, the $\mathrm{R}_{\mathrm{Sa}}$ and $\mathrm{R}_{\mathrm{Sp}}$ values were changed simultaneously by $1 \%$. According to the test results, the coefficient of suppression of the influence of changes in the background electrical conductivity was about 90 at the $+20 \%$ difference of $\mathrm{C}_{\mathrm{Sp}}$ and about 50 - at the $-20 \%$ difference of $\mathrm{C}_{\mathrm{Sp}}$. The obtained values are about 10 times higher than those achieved in the previously created devices [36].

4. Conclusions. In this work, we have developed a new bridge circuit for determination of local changes in the electrical conductivity of the buffer solution when working with electrically conductive analytes. For this purpose, a novel method of balancing the bridge circuit to the quasi-equilibrium state was applied. Both the bridge circuit and the method of its balancing are based on the use of digital generators of test signals in the branches of the bridge with an adjustable ratio between their amplitudes and initial phases. This enables a deeper suppression of common mode interference when using non-identical conductometric transducers in a wide frequency range. The detailed algorithm of operation of the differential conductometric channel was developed using a vector modeling of the measurement process. The experimental verification of the effectiveness of the developed method showed the possibility to achieve the coefficient of suppression of the influence of changes in the background electrical conductivity about 10 times higher than when using previously created devices under $20 \%$ difference between the sensors' capacitances. Such characteristics can significantly expand the area of application of the conductometric biosensors, and in particular, their use in the study of the electrically conductive analytes. Moreover, the obtained characteristics will increase the metrological reliability of this type of measurements.

The work was supported by National Academy of Sciences of Ukraine within the framework of the State Budget Program "Support for the Development of Priority Areas of Scientific Research" (Code: 6541230), the target program of scientific research of National Academy of Sciences of Ukraine "Smart" sensor devices of a new generation based on modern materials and technologies" and the grant of National Academy of Sciences of Ukraine for research laboratories/groups of young scientists of NAS of Ukraine for conducting investigations within the priority directions for development of science and technology in 2021 (grant 25/02-2021(2)).

1. Turner A.P.F., Karube I., Wilson G.S. Biosensors: Fundamentals and applications. New York: Oxford University Press, $1987.770 \mathrm{p}$.

2. Varnakavi Naresh, Nohyun Lee. A Review on Biosensors and Recent Development of Nanostructured Materials-Enabled Biosensors. Sensors. 2021. Vol. 21 (4). Article 1109. DOI: https://doi.org/10.3390/s21041109.

3. Janata J. Conductometric sensors. In: Principles of Chemical Sensors. Boston: Springer, 2009. Pp. 241266. DOI: https://doi.org/10.1007/b136378

4. Lee S-M., Lee W-Y. Determination of heavy metal ions using conductometric biosensor based on sol-gel immobilized urease. Bulletin of the Korean Chemical Society. 2002. Vol. 23. No 8. Pp. 1169-1172.

5. Adley C.C., Ryan M.P. Conductometric biosensors for high throughput screening of pathogens. In: High Throughput Screening for Food Safety Assessment: Biosensor Technologies, Hyperspectral Imaging and Practical Applications. Cambridge: Woodhead Publishing Ltd, 2014. Pp. 315-326.

6. Perera G.S, Ahmed T., Heiss L., Walia S., Bhaskaran M., Sriram S. Rapid and selective biomarker detection with conductometric sensors. Nano-Micro Small. 2021. Vol. 17. Article 2005582. DOI: https://doi.org/10.1002/smll.202005582

7. Braiek M., Djebbi M.A., Chateaux J-F., Jaffrezic-Renault N. A conductometric sensor for potassium detection in whole blood. Sensor and Actuators B: Chemical. 2016. Vol. 235. Pp. 27-32. DOI: https://doi.org/10.1016/j.snb.2016.05.050

8. Sosovska O., Korpan Y., Vocanson F., Jaffrezic-Renault N. Conductometric chemosensors based on calixarenes for determination of amines and amino acids. Sensor Letter. 2009. Vol. 7. Pp. 989-994. DOI: https://doi.org/10.1166/sl.2009.1186

9. Watson L.D., Maynard P., Cullen D.C., Sethi R.S., Brettle J., Lowe C.R. A microelectronic 
conductometric biosensor. Biosensors. 1987-1988. Vol. 3(2). Pp. 101-115. DOI: https://doi.org/10.1016/s0265928x(87)80003-2

10. Sheppard N.F., Tucker R.C., Wu C. Electrical conductivity measurements using microfabricated interdigitated electrodes. Analytical Chemistry. 1993. Vol. 65(9). Pp. 1199-1202. DOI: https://doi.org/10.1021/ac00057a016

11. Lee W.Y., Kim S.R., Kim T.H., Lee K.S., Shin M.C., Park J.K. Sol-gel-derived thick-film conductometric biosensor for urea determination in serum. Analytica Chimica Acta. 2000. Vol. 404(2). Pp. 195-203. DOI: https://doi.org/10.1016/S0003-2670(99)00699-6

12. Jacobs P., Suls J., Sansen W. Performance of a planar differential-conductivity sensor for urea. Sensor and Actuators B: Chemical. 1994. Vol. 20. Issues 2-3. Pp. 193-198.

13. Hintsche R., Moller B., Dransfeld I., Wollenberger U., Scheller F., Hoffmann B. Chip biosensors on thinfilm metal electrodes. Sensor and Actuator B: Chemical. 1991. Vol. 4. Issues 3-4. Pp. 287-291. DOI: https://doi.org/10.1016/0925-4005(91)80124-3

14. Melnyk V.G., Dzyadevych S.V., Novik A.I., Pogrebnyak V.D., Slitskiy A.V., Lepikh Ya.I., Lenkov S.V., Procenko V.O. Ensuring of reliability of metrological characteristics of the conductometric systems with differential sensors. Sensor Electronics and Microsystem Technologies. 2011. Vol. 8(4). Pp. 46-52. DOI: https://doi.org/10.18524/1815-7459.2011.4.119304

15. Melnyk V.G., Dzyadevych S.V., Ivashchuk A.V., Ulyanova V.A., Lepikh Ya.I., Romanov V.O. The experimental studies of microelectronic transducers for conductometric biosensor systems. Sensor Electronics and Microsystem Technologies. 2011. Vol. 8(3). Pp. 81-90. DOI: https://doi.org/10.18524/1815-7459.2011.3.118131 (Rus).

16. Latif U., Dickert F.L. Conductometric sensors for monitoring degradation of automotive engine oil. Sensors. 2011. Vol. 11(9). Pp. 8611-8625. DOI: https:doi.org/10.3390/s110908611

17. Sergeyeva T.A., Lavrik N.V., Rachkov A.E., Kazantseva Z.I., Piletsky S.A., El'skaya A.V. Hydrogen peroxide-sensitive enzyme sensor based on phthalocyanine thin film. Analytica Chimica Acta. 1999. Vol. 391. Pp. 289297.

18. Berezhetska O., Korpan Y., Gonchar M. Conductometric biosensor based on flavocytochrome b2 for Llactate determination. Sensor Letter. 2011. Vol. 9. Pp. 2388-2394.

19. Khadro B., Namour P., Bessueille F., Leonard D., Jaffrezic-Renault N. Validation of a conductometric bienzyme biosensor for the detection of proteins as marker of organic matter in river samples J. Environ. Sci. (China). 2009. Vol. 21. Pp. 545-551.

20. Barsoukov E., Macdonald J.R. Impedance spectroscopy: Theory, experiment, and applications. WileyInterscience, John Wiley \& Sons, Inc., 2005.

21. Brett C.M.A., Brett A.M.O. Electrochemistry - Principles, methods and applications. Oxford University Press, $1993.427 \mathrm{p}$.

22. Grossi M., Riccò B. Electrical impedance spectroscopy (EIS) for biological analysis and food characterization: A review. J. Sens. Sens. Syst. 2017. No 6. Pp. 303-325. DOI: https://doi.org/10.5194/jsss-6-303-2017

23. Novitskiy S.P., Pechnikov A.L. Improving an estimation accuracy of research object parameters by the impedance spectroscopy method. Science Bulletin of the Novosibirsk State Technical University. 2015. Vol. 60(3). Pp. 48-57. DOI: https://doi.org/10.17212/1814-1196-2015-3-48-57 (Rus).

24. Sekushin N.A. Properties of Warburg and Gerischer diffusion impedances in low frequencies region. Bulletin of Komi Science Center of Ural Branch of the Russian Academy of Sciences. 2010. Vol 4. No 4. Pp. 22-26. URL: http://www.izvestia.komisc.ru/old/Archive/i04/sekushin.pdf (accessed 05.07.2021) (Rus).

25. Fang T.T. Amino acid pattern for analysis of fruit juice authenticity. In: Analysis of non-alcoholic beverages. Springer-Verlag Berlin Heidelberg, 1988. Pp. 51-68. DOI: https://doi.org/10.1007/978-3-642-83343-4

26. Winter G., Todd C.D., Trovato M., Forlani G., Funck D. Physiological implications of arginine metabolism in plants. Frontiers in Plant Science. 2015. Vol. 6. Article 534. Pp. 1-14. DOI: https://doi.org/10.3389/fpls.2015.00534

27. Saiapina O.Y., Dzyadevych S.V., Jaffrezic-Renault N., Soldatkin O.P. Development and optimization of a novel conductometric bi-enzyme biosensor for L-arginine determination. Talanta. 2012. No 92. Pp. 58-64. DOI: https://doi.org/10.1016/j.talanta.2012.01.041

28. Stasyuk N., Smutok O., Gayda G., Vus B., Koval'chuk Y., Gonchar M. Bi-enzyme L-arginine-selective amperometric biosensor based on ammonium-sensing polyaniline-modified electrode. Biosens. Bioelectron. 2012. Vol. 37(1). Pp. 46-52. DOI: https://doi.org/10.1016/j.bios.2012.04.031

29. Verma N., Singh A.K., Kaur P. Biosensor based on ion selective electrode for detection of L-arginine in fruit juices. J. Anal. Chem. 2015. Vol. 70(9). Pp. 1111-1115. DOI: https://doi.org/10.1134/S1061934815090129

30. Zhybak M T., Fayura L.Y., Boretsky Yu.R., Gonchar M.V., Sibirny A.A., Dempsey E., Turner A., Korpan Ya.I. Amperometric L-arginine biosensor based on a novel recombinant arginine deiminase. Microchimica Acta. 2017. Vol. 184(8). Pp. 2679-2686. DOI: https://doi.org/10.1007/s00604-017-2290-4 
31. Singh A.K., Sharma R., Singh M., Verma N. Electrochemical determination of L-arginine in leukemic blood samples based on a polyaniline-multiwalled carbon nanotube-magnetite nanocomposite film modified glassy carbon electrode. Instrum. Sci. Technol. 2020. Vol. 48(4). Pp. 400-416. DOI: https://doi.org/10.1080/10739149.2020.1734934

32. Melnyk V.G., Onyshchenko I.V., Rubanchuk M.P., Slitskiy O.V. Differential conductometric system with improved suppression of common-mode interferences. Tekhnichna Electrodynamica. 2015. No 2. Pp. 75-82. (Rus)

33. Melnyk V.G., Slitskiy A.V., Vasylenko A.D. The quasi balanced conductometric bridge for biosensor system with balancing modulus and phase. Sensor Electronics and Microsystem Technologies. 2016. Vol. 13(3). Pp. 91-100. DOI: https://doi.org/10.18524/1815-7459.2016.3.78649 (Rus)

34. Melnyk V.G., Borschov P.I., Beliaev V.K., Vasylenko O.D., Lameko O.L., Slitskiy O.V. Improvement generating of the test signals for determination of the impedance parameters in wide frequency range. Sensor Electronics and Microsystem Technologies. 2020. Vol. 17(2). Pp. 60-72. DOI: https://doi.org/10.18524/1815$\frac{7459.2020 .2 .205825}{35.26}$

35. Melnyk V.G., Borschov P.I., Beliaev V.K., Vasylenko O.D., Lameko O.L., Slitskiy O.V. Implementation and experimental research of the test and reference signals digital generators for impedance measurement in wide frequency band. Sensor Electronics and Microsystem Technologies. 2020. Vol. 17(3). Pp. 27-39. DOI: https://doi.org/10.18524/1815-7459.2020.3.212951

36. Melnyk V.G., Vasilenko O.D., Dudchenko A.E., Pogrebnyak V.D. Research common mode rejection in conductometric biosensor system with differential sensors. Sensor Electronics and Microsystem Technologies. 2014. Vol. 11(3). Pp. 49-61. DOI: https://doi.org/10.18524/1815-7459.2014.3.108258 (Rus).

37. Melnyk V.G., Semenycheva L.N., Vasylenko A.D. Investigation of characteristics of transforming of the differential conductometric circuit for biosensors systems. Sensor Electronics and Microsystem Technologies. 2011. Vol. 8(4). Pp. 53-62. DOI: https://doi.org/10.18524/1815-7459.2011.4.119355 (Rus).

\section{ПІДВИЩЕННЯ ЧУТЛИВОСТІ ТА МЕТРОЛОГІЧНОЇ НАДІЙНОСТІ ПЕРЕТВОРЕННЯ ЗМІН ЛОКАЛЬНОЇ ЕЛЕКТРОПРОВІДНОСТІ РОЗЧИНУ В ДИФЕРЕНЦІАЛЬНІЙ КОНДУКТОМЕТРИЧНІЙ БІОСЕНСОРНІЙ СИСТЕМІ}

В.Г. Мельник ${ }^{1}$, докт. техн. наук, П.І. Борщов ${ }^{1}$, канд. техн. наук, С.В. Дзядевич ${ }^{2}$, докт. біолог. наук,

О.Я. Саяпіна ${ }^{2}$, канд. біолог. наук, О.Д. Василенко ${ }^{1}$, канд. техн. наук

${ }^{1}$ Інститут електродинаміки НАН України,

пр. Перемоги 56, Київ, 03057, Україна.

E-mail: melnik@ied.org.ua

${ }^{2}$ Інститут молекулярної біології та генетики НАН України,

вул. Заболотного, 150, Київ, 03680, Україна.

E-mail: $\quad \underline{\text { dzyad@yahoo.com; oysaiapina@gmail.com }}$

Диференціальний метод кондуктометричних вимірювань не вирішує повністю проблему впливу зміни фонової електропровідності робочих буферних розчинів на результати перетворення відгуків біосенсора. Зміна фонової електропровідності буферного розчину під час додавання високопровідного аналіту діє як синфазна завада $i$ викликає адитивну похибку. У статті розглянуто новий метод вимірювання та структуру пристрою для кількісного визначення аналітів, які забезпечують значне зменшення похибки вимірювання, пов'язаної зі зміною фонової електропровідності, викликаної введенням аналіту в робочий розчин перед генерацією інформаційного сигналу. Наведено структурну схему пристрою і векторну модель процесу балансування його вимірювального кола. Показано переваги розробленого методу $і$ біосенсорного аналізатора задля застосування за можливих змін параметрів перетворювача та умов вимірювання. Бібл. 37, рис. 4.

Ключові слова: диференціальні кондуктометричні біосенсори, імпеданс, вимірювання, синфазний вплив, еквівалентна електрична модель. 